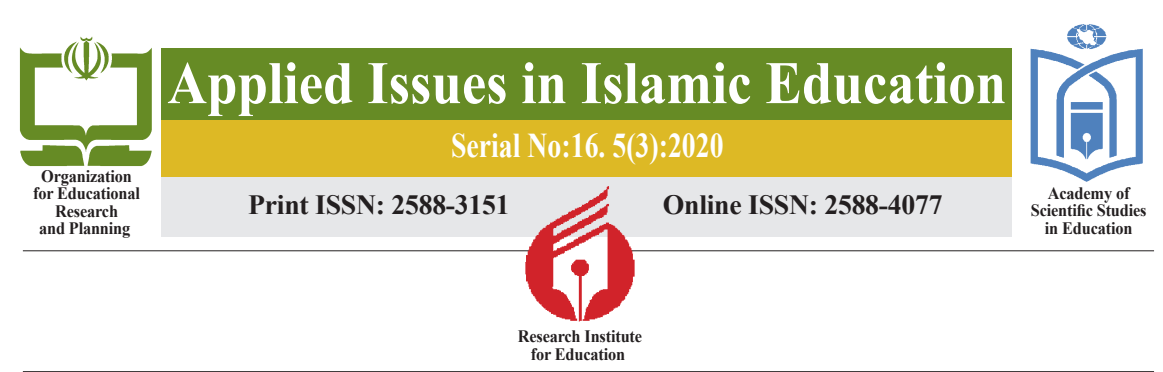

\title{
The Relationship between Mothers' Parenting Styles and the Identity Base and Religiosity of Female Students in Senior High School
}

Saboora Tahmaseb-Nejad ${ }^{1}$, Khadijeh Arin ${ }^{2}$

- Objectives: The purpose of this study was to investigate the relationship between mothers' parenting styles and the identity base and religiosity of the female students at senior high school in the humanities field in Babol, Iran.

- Method: The research method is descriptive method of correlation. The statistical population of this study consisted of all female school students at senior high school in the field of humanities, who studied in the Babol public schools in the school year 2019-2020. Through simple sampling method, 120 students and their mothers were selected. The tools were the Identity Base Questionnaire (Adams, 1989), the Aryan Muslim Religiosity Questionnaire (2000) and the Baumrind's Parenting Styles Questionnaire (Esfandiari, 1996). For the analysis of the data, descriptive frequency index and inferential statistics of Spearman and Pearson correlation coefficient and Kolmogorov-Smirnov test were used.

- Findings: The findings showed there was a significant relationship between authoritative, negligent and authoritarian parenting styles and the identity base of female students. However, there was no significant relationship between parenting styles and girls' religiosity.

- Conclusion: Therefore, one of the ways to strengthen the identity base of students is to help parents to adopt an authoritative approach in educating their daughters.

Keywords: parenting styles, identity, religiosity, Female students, senior High School.

Citation: Tahmaseb-Nejad,S., \& Arin,K. (2020). The Relationship between Mothers' Parenting Styles and the Identity Base and Religiosity of Female Students in Senior High School. Applied Issues in Islamic Education, 5(3): 83-100.

1. MA in educational sciences, Faculty of Psychology and Educational Sciences, Allameh Tabataba'i University, Tehran, Iran.

E-mail: saboratahmasbnezhad1364@gmail.com. (D) 0000-0001-8665-8660

2. Corresponding Author: Assistant Professor, Faculty of Psychology and Educational Sciences, Allameh Tabataba'i University, Tehran, Iran.

E-mail: kharyan@Hotmail.com. (D) 0000-0002-7898-4009 



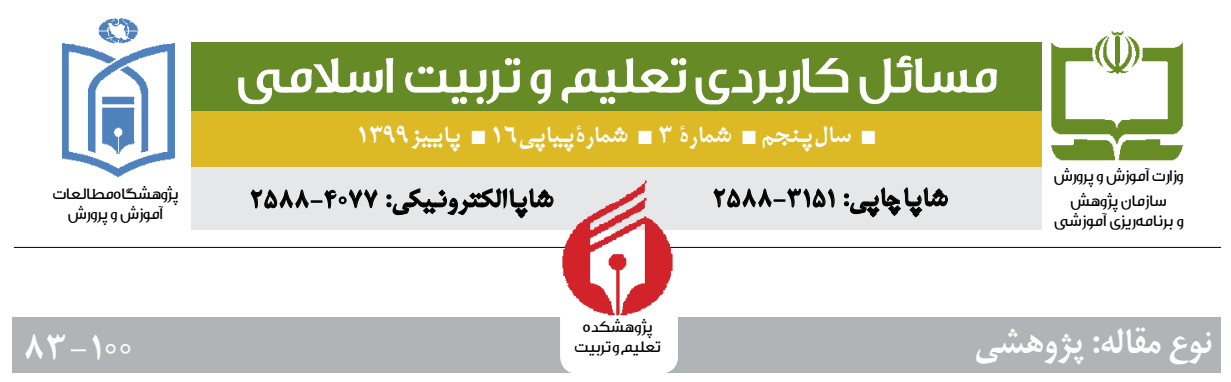

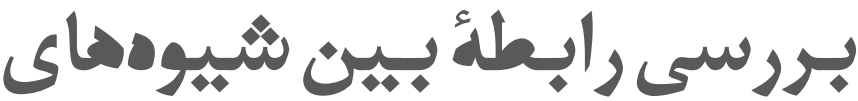 فرزئديرورى مادران

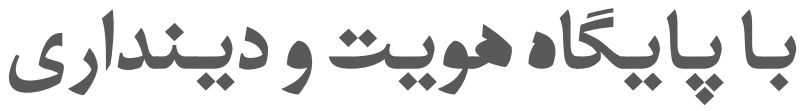 دانشُ آموزان دخُتر ان دوره مثنوسطه دوم

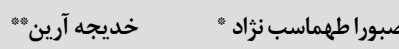

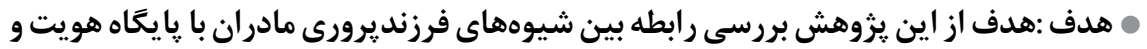

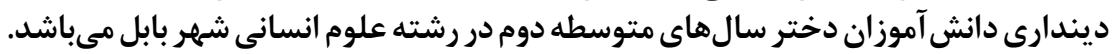

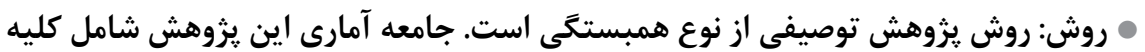

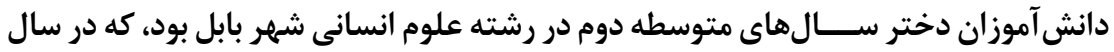

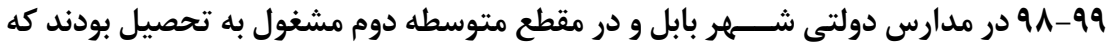

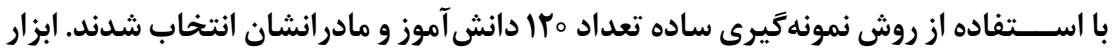

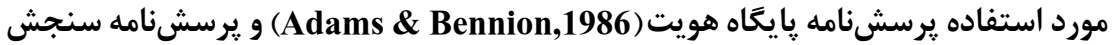

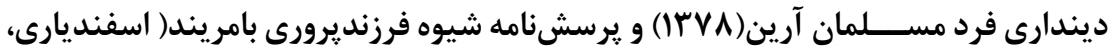
ضر يب هم (lFF

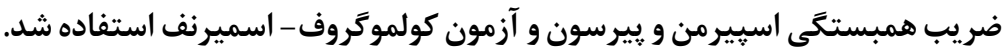

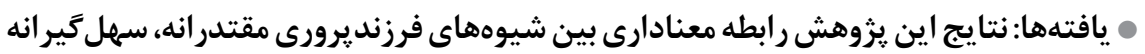

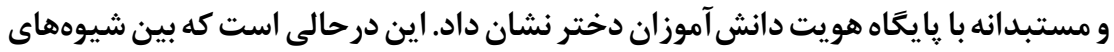

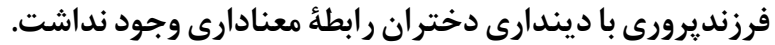

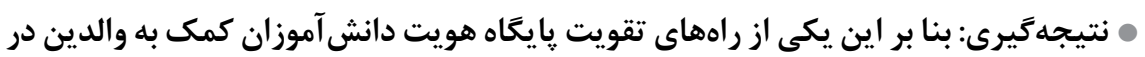

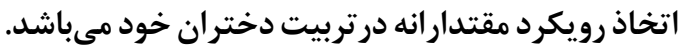

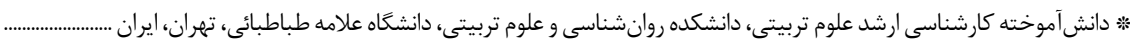
Email: saboratahmasbnezhad1364@gmail.com (iD) 0000-0001-8665-8660 


\section{مقدمه}

در تربيـت افراد، نهادها، عوامل و افراد كوناكون نقـش دارند. يكى از عوامل مؤثر در شكل كيرى شخصيت فرد خانواده است. محيط خانه نخستين و بادوامترين عاملى است كه

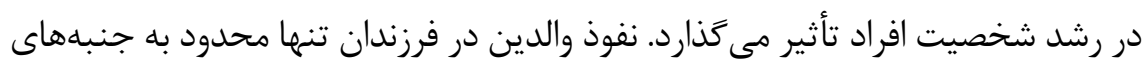

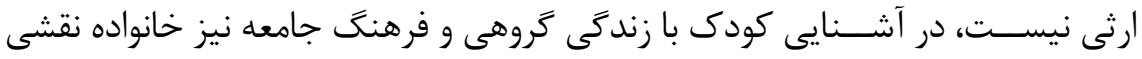

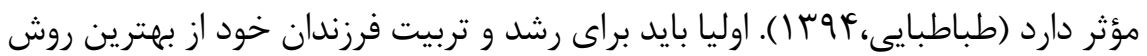

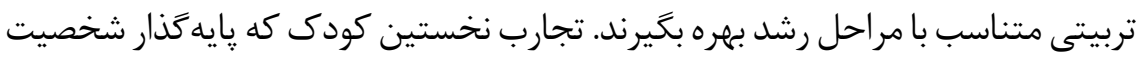

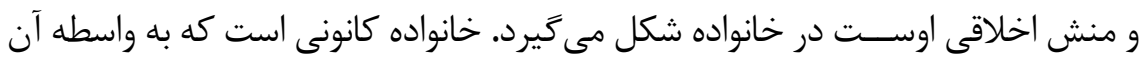

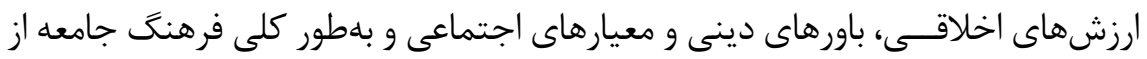

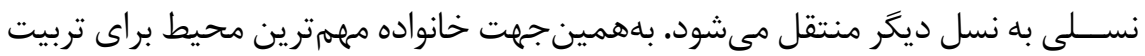

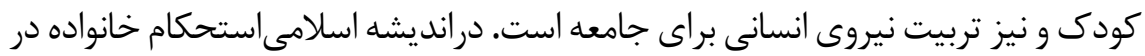

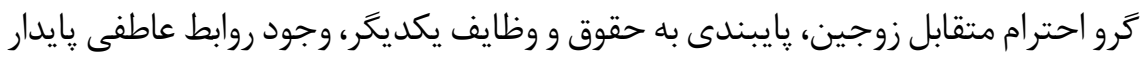

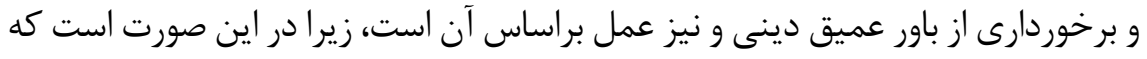

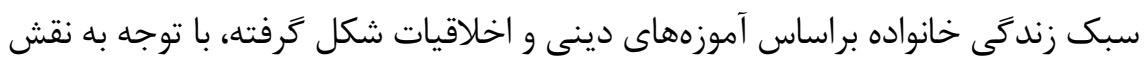

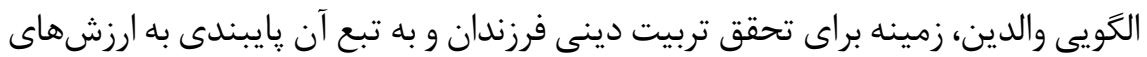

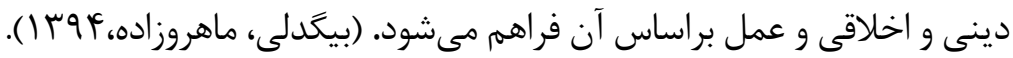

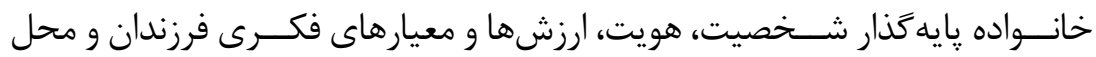

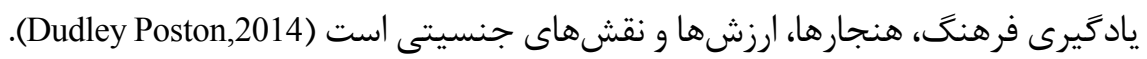

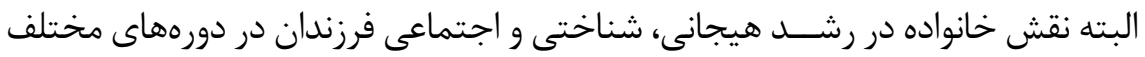

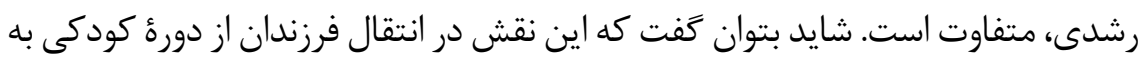

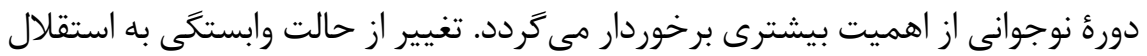

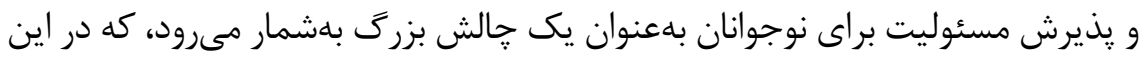

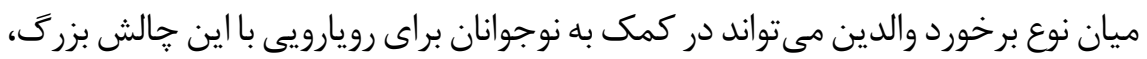

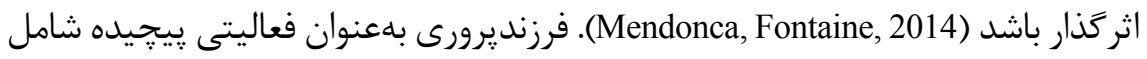
روشهاو رفتارهاى ويزهاى اســت كه بهطور مجزا يا در تعامل با يكديكر بر رشد كودى

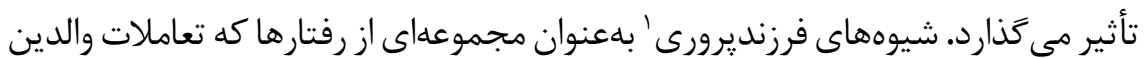


و كودى را در طول دامنهُ كســترداى از موقعيتها توصيف مى كند و يك جوّ تعاملى

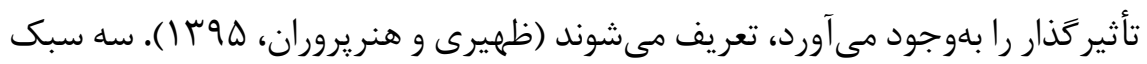

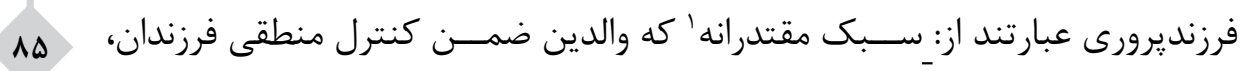

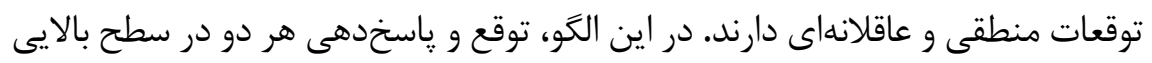

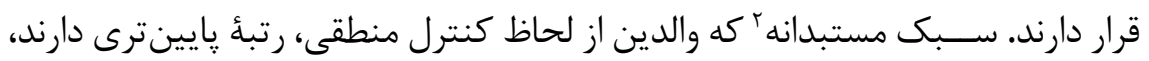
كمتر با فرزندان صميمى هستند و بيشتر بر اعمال قدرت و انضباط اجبارى تأكيد دارند.

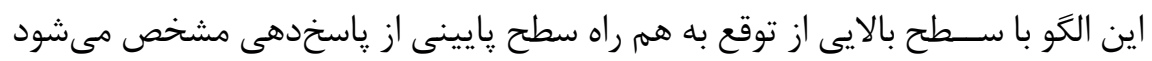

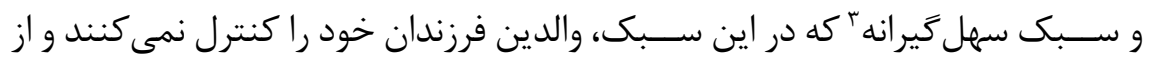

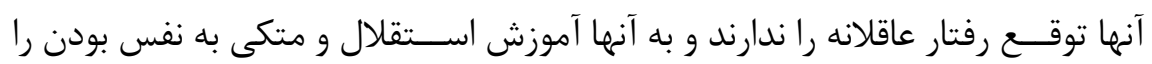

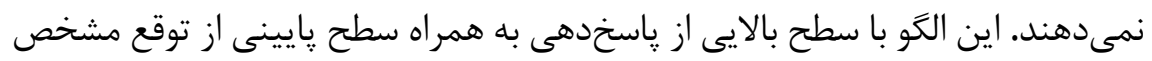

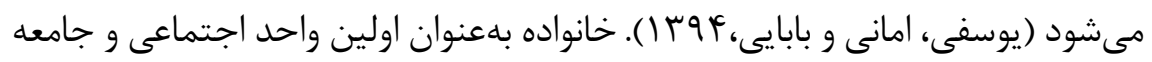

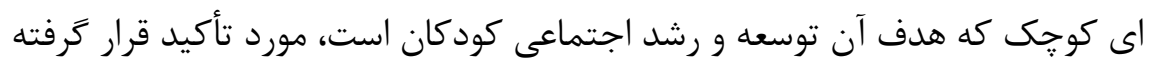

دوران نوجوانى و و جوانى يكى از بحرانىترين ادوار زندگى انسان محسوب مىشود.

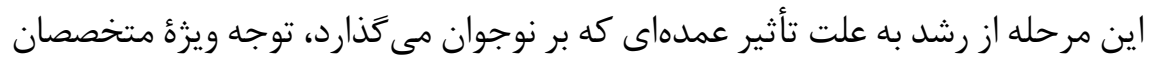

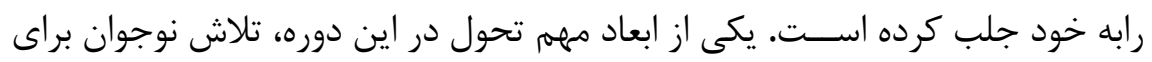

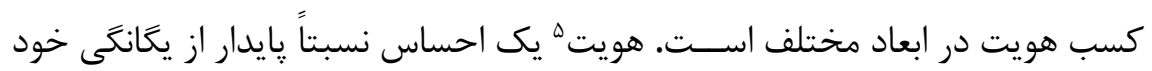

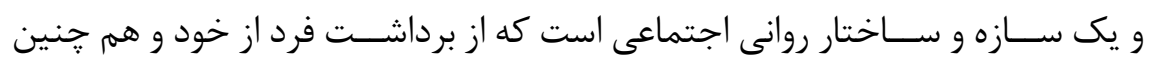

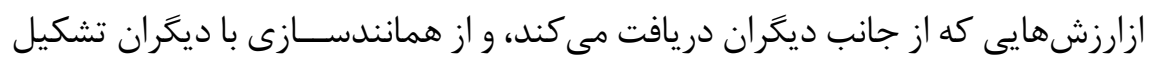

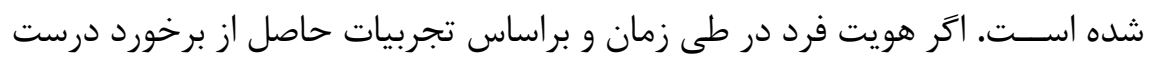

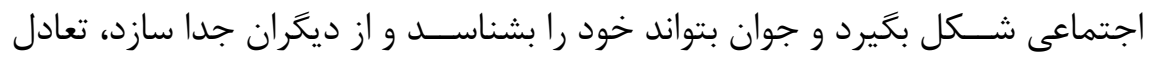

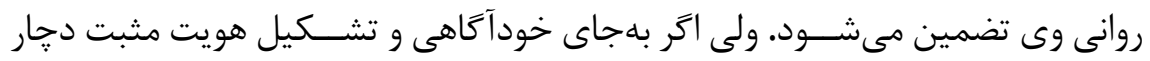

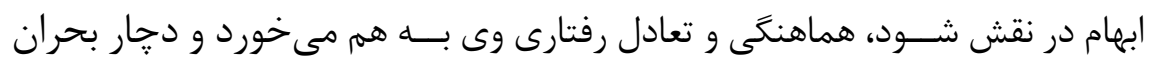
هويت مى كردد.

1. Authoritative

2. authoririan

3. permissive

4. adolescence

5. identity 
مارسيا (Marcia, 1980) با تركيب حضور يا فقدان اين معيارها (عبور از بحران و كسب

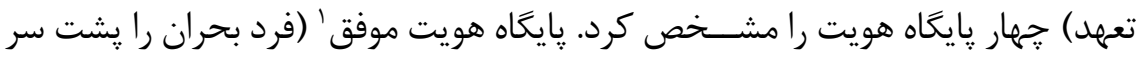

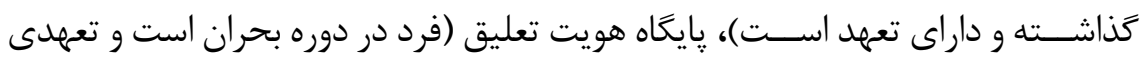
ايجاد نكرده اســت). يايگًاه هويت زودرس (فرد بحرانى نداشــته، اما داراى تعهد است)، پايعاه هويت سردر گمّ (فرد درحال حاضر نه بحران دارد و نه داراى تعهد است).

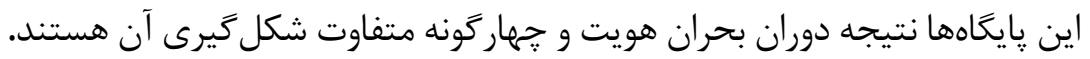

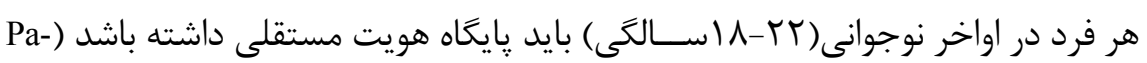
palya, 2016 هويت ممكن اســت تركيبى از اثر بخشى و دانش شناختى باشد تا شنات تنهــــاو هويت فرهنغى و ملى نقش مهرمى در فرآيند هويتيابسـى كلى افراد دارد (2011, Savicki \& Cooley موضوعهاى گوناگون و انتخاب موارد مناسب نحوه جلوه خود را در نظر ديگران بهصورتى موجه تعيين كنند. به اين صورت كه محيطهاى فرهنگى متفاوت موجب تفاوت در نحوه شكل گيرى ديد گاههاى افراد مىشوند (Erikson,1970). هويت يك جنبه اساسى و درونى است كى به كمك آن يك فرد با حذشته اش مرتبط مى

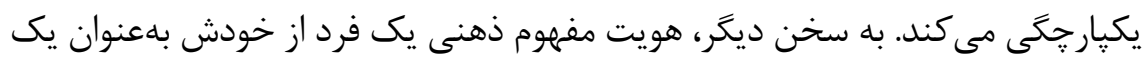
فرد بىنظير و داراى ثبات اسـت (Berzonsky \& Kuk, 2005). مدلهاى فرهنگى توسعه هويت بايد به زمينه و بستر فرهنكى بيش از بيش توجه كنند و هويت دينى تحت تأثير آموزههاى دينى مدارس قرار دارد. هويت دســتاورد مهلم رشــد شخصيت در نوجوانى و كامى مهلم به سوى ثمر بخش بودن است (حيدرى ورمضانى باصرى، سوس ()).

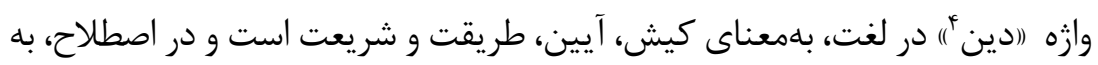
مجموعه اصول، قواعد بنيادى، احكام و دستوراتى اطلاق مى شود كه از سوى خدا به انسان داده شده است. باورهاى دينى عنصر مشتر ك و مر كزى نظامهاى معنادارى بسيارى از افراد

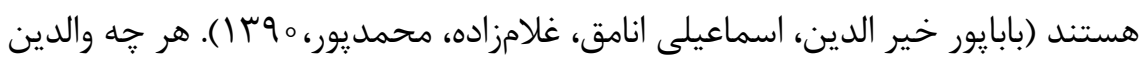
رفتارهاى محبت آميز، يذيرش و مصاحبت بيشــترى در ارتباط با فرزندان نشان دهند، 
فرايندهايى كه منجر به رشد هويت يِيشرفته مى گردند را بيشتر تقويت مى كنند (بابايور و

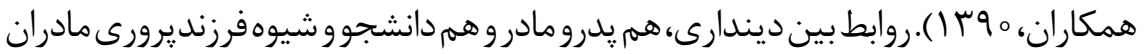

و خودتنظيمى تحصيلى، ييشرفت تحصيلى و رفتار مخاطرهآميز دانشجويان مورد بررسى

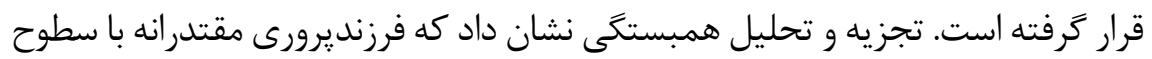

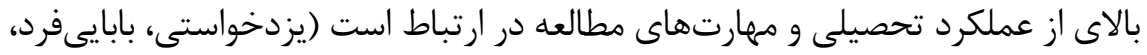

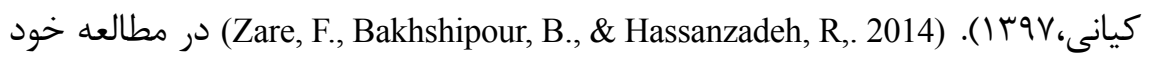
نشــان دادند كه ميان شيوه فرزنديرورى مســتبدانه و سلامت روانى رابطهُ منفى و ميان شــيوه فرزنديرورى مقتدرانه و ســلامت روانى رابطهُ مثبت وجــــود دارد. همجنين نتايج

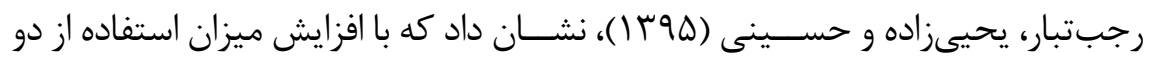

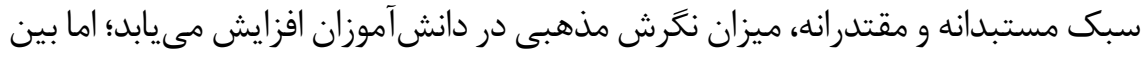

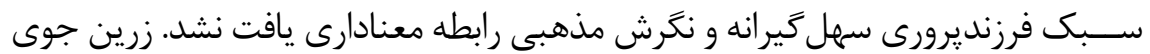

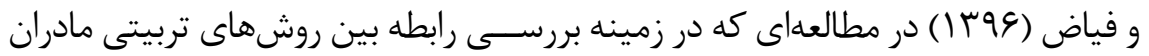

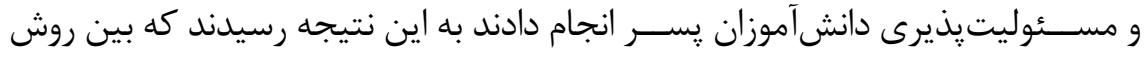

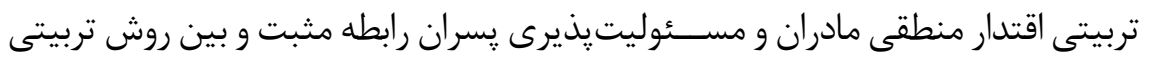

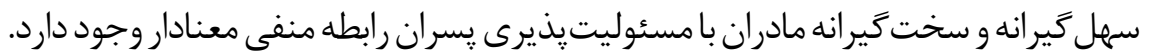
يزوهشـــران در مطالعه خود يادآور شدند كه پِّران، مادران خود را مراقبت بيش از

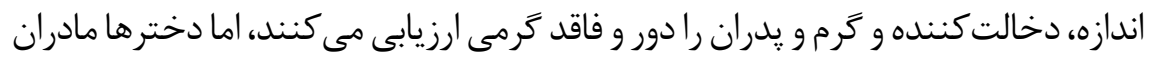

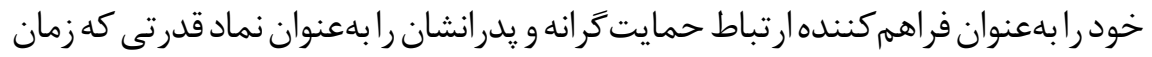
كمى را با آن ها مى حذر انند، ارزيابى مى كنند (Uji, Sakamoto, Adachi. \& Kitamur, 2014).

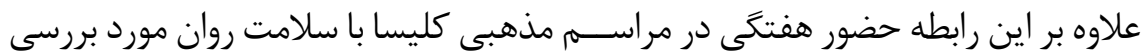
قرار كرفت. يافتههاى اين يزوهش نشــان داد، كودكانى كه در مراسمهاى مذهبى حضور بيشترى داشتند يرخاشكرى كمترى از خود در موقعيتهاى خانه و مدرسه نشان مى دادند

. (Abbotts, Williams, Sweeting, West, 2004)

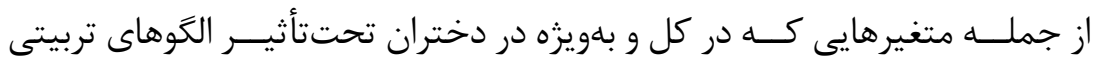
اســت ديندارى است. ديندارى يعنى داشــتن اهتمام دينى بهنحوى كه نكَرش، كرايش

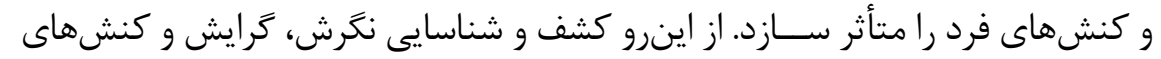

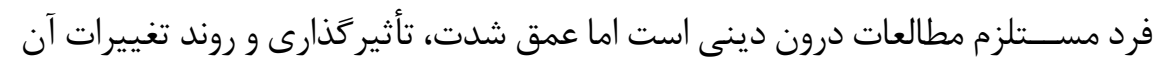


مستلزم وارسى هاى بيرونى است. مطهرى (هوس ( ) سه مؤلفه اعتقادات، احكام و اخلاق را از مؤلفههاى كليدى ديندارى تعريف نموده است محمدى شوره و فرجاللمى (צ૧ ا ) در مطالعه اي كه در زمينه ديندارى دختران انجام دادند دريافتند كه در نظام آموزشعاهى كســانى كه در تربيت دختران نقش كليدى دارند مثل اولياء مدرســـه از قبيل معلمان، معاونان و مربيان يرورشى در ديندارى دانشآموزان نقش كليدى از خود به جا مى گذارند. با توجه به آنجه كفته شد تحقيق حاضر در يى یاسخَّويى به اين سؤال اين است كه آيا بين شيوههاى فرزنديرورى مادران و ديندارى دانشآموزان دخترشان رابطه وجود دارد و آيا بين شيوههاى فرزنديرورى مادران و هويت دانشآموزان دخترشان رابطه وجود دارد؟

\section{روش يزوهش}

در اين يزوهش از دانشآموز دختر و مادر همان دانشآموزان اســـفاده شــده است. جامعه آمارى اين يزوهش شامل كليه دانشآموزان دختر سالهاى متوسطه دوم در رشته علوم انســانى شهر بابل بود، كه در سال 99-91 در مدارس دولتى شهر بابل و در مقطع متوسطه دوم مشغول به تحصيل بودند. حجم نمونه در اين جامعه با توجه به اينكه روش ري

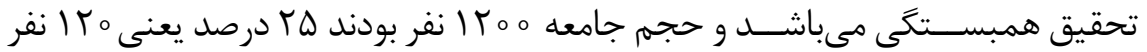
بهطور تصادفى ساده انتخاب شدند به اين صورت كه جهار مدرسه بهصورت تصادفى در بين مدارس علوم انسانى انتخاب شدند ويرسشنامه را در بين دانشآموزان توزيع كرديم و از ه ا مادر همين دانشآموزان براى اجراى يرسشنامه استفاده كرديم.

\section{ابزار جمع آورى اطلاعات}

ابزار جمع آورى اطلاعات در اين تحقيق عبارتند از: يرسشنامه شيوههاى فرزنديرورى

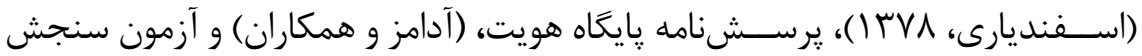

$$
\text { ديندارى فرد مسلمان (آرين، IVVV). }
$$

\section{يرسشنامه فرزنديرورى تجديد نظر شده اسفنديارى (IFVF)} اين يرســشنامه توسط بامريند ( 999 (19) تدوين شــده است. اسفنديارى بر اساس

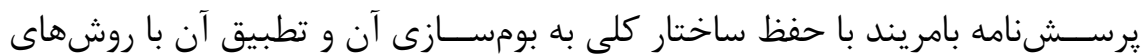




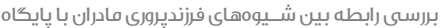

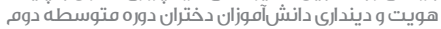

Ar-100

تربيتى اســلام يرداخته اســت كه يس از انطباق با مبانى تربيتى اســلامى در اختيار تعدادى متخصصان روانشــناس تربيتى و صاحب نظران تعليم و تربيت قرار داده است

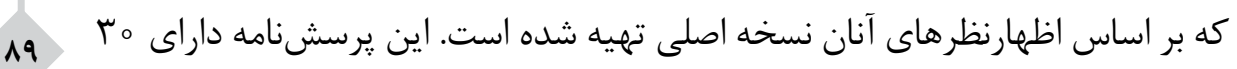
گويه است كه سه شيوه تربيتى مادران يعنى شيوه سهل گيرانه و سخت گيرانه و اقتدار منطقى را مورد مطالعه قرار مى دهد. اين يرسشنامه شامل هب گويه است كه ده گويه به شيوه سهل گيرانه ( جملات شماره (

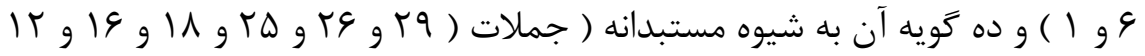

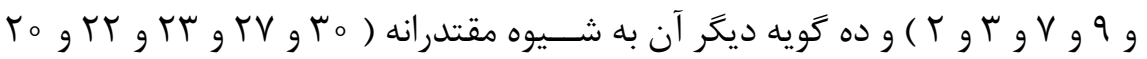

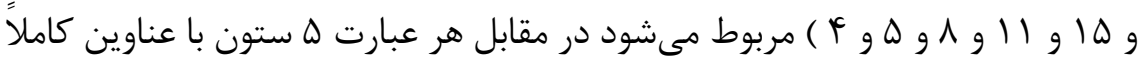
موافقم، موافقم، نه موافق و نه مخالفم، مخالفم و كاملاً مخالفم قرار دارد كه به ترتيب از

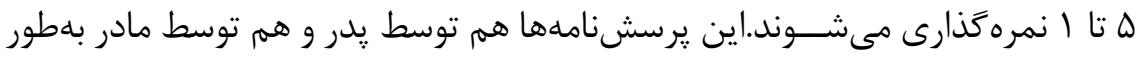

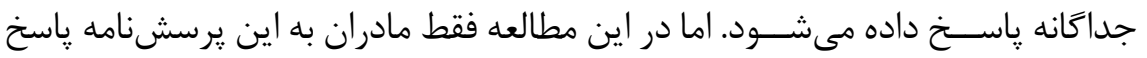
دادند. با جمع نمرات جملات مربوط به هر شيوه سه نمره مجزا بهدست مى آيد و نمره مربوط به هر شــيوه كه بيشتر باشد بهعنوان فرزنديرورى در نظر زرفته مىشود. البته در بهترين حالت نمره هر شيوه فرزنديرورى، معدل يرسشنامه يدر و مادر است اما در اين مطالعه فقط نمره مادران مبنا قرار زرفته است روايى محتواى اين ابزار توسط هرئ نفر از صاحب نظران روانشناســى و روانيزشكى مورد بررسى و تأييد قرار كرفته است

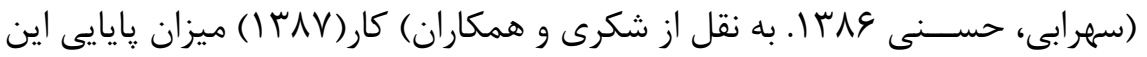

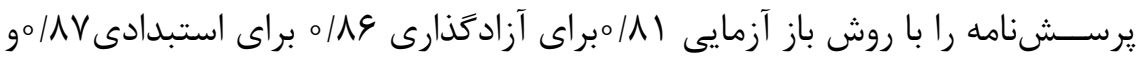

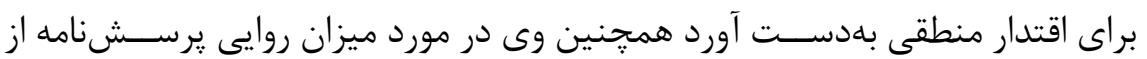
روش روايى افتراقى اســتفاده كرد كه نتيجه ززارش شـــده به اين صورت بوده مستبد

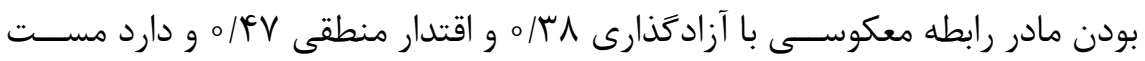

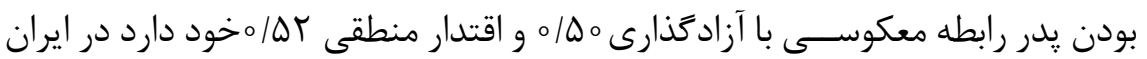

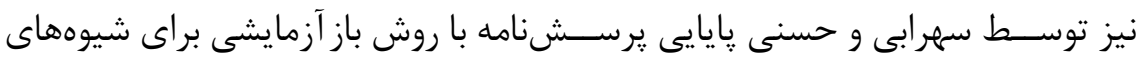
سهل گيرى 9/ه براى شيوههاى اســتبدادى VV/ و براى شيوههاى قاطع و اطمينان

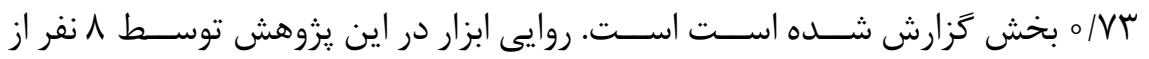




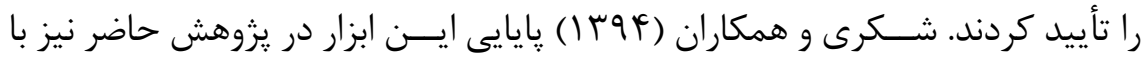
اســفاده از روش باز آزمايى به روى ه ب نفر از معلمين به فاصله زمانى سه هفته

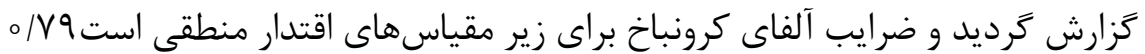

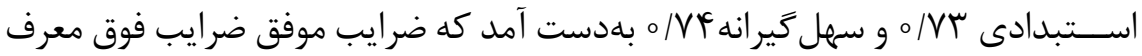

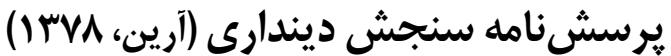

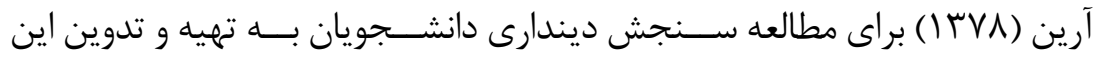

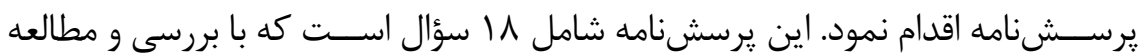

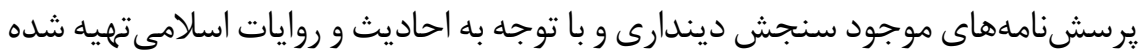
است. اين يرسشنامه سه مؤلفه باور دينى، اعمال دينى و تعالى الهى را مورد اندازمخيرى

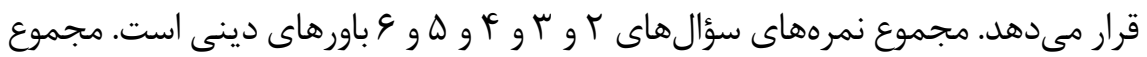

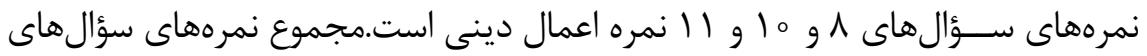

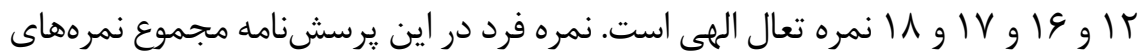

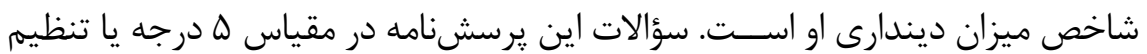
شده است (خيلى زياد، زياد، متوسـط، كم و خيلى كم). نمرهذارى در اين يرسشنامه دئه به اين صورت اسـت كه به קاســخ خيلى كم نمره ا و به پاسخ خيلى زياد نمره له داده

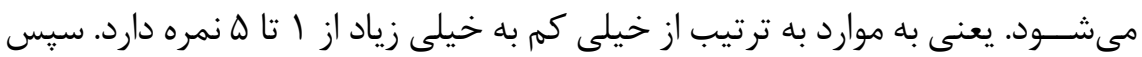

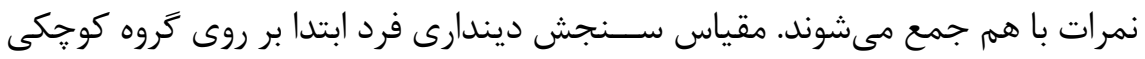

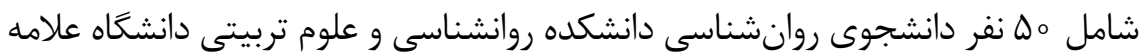

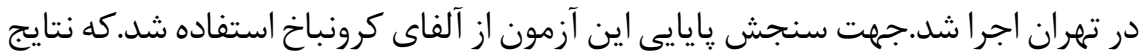

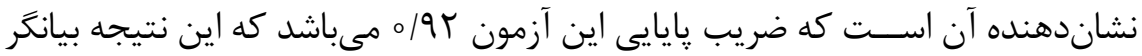

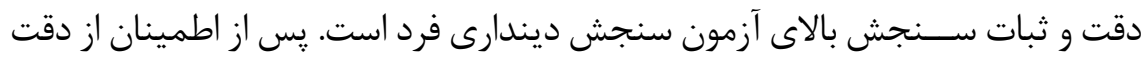

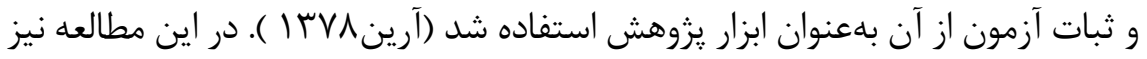

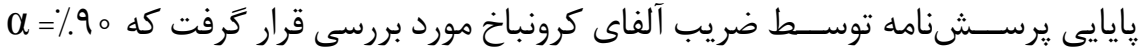




\section{يرسشنامه يايعاه هويت نوجوانان (Bennion, \& Adams,1986)}

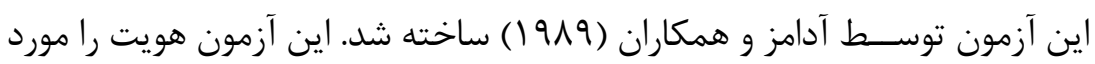

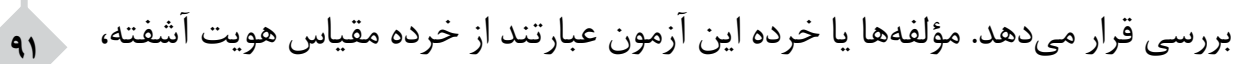

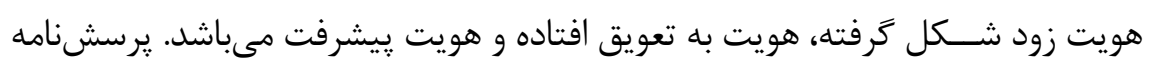

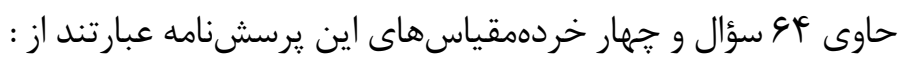

$$
\text { ا. ا. خردمقياس هويت آشفته، }
$$

$$
\text { r. خردهمقياس هويت زود شكل خرفته، }
$$$$
\text { r. خردهمقياس هويت به تعويق افتاده }
$$

$$
\text { F أ. خردمدقياس هويت تحقق يافته. }
$$

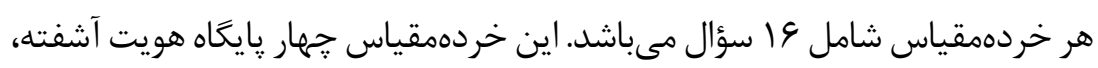

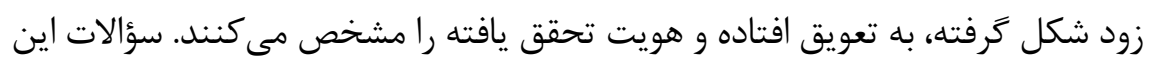
آزمون در مقياس 4 درجهاى تنظيم شده است به اين صورت الف) كاملاً موافقم، موافقم،

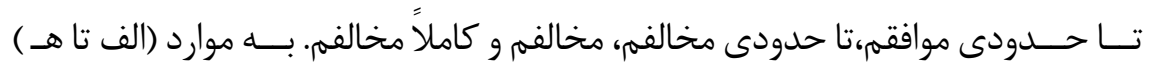

$$
\text { به ترتيب نمره و- ه- }
$$

سؤسال هاى 1-

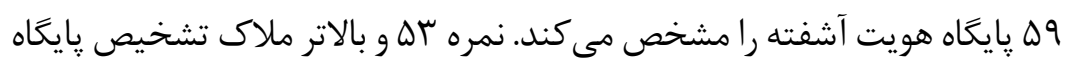

$$
\text { هويت آشفته مىباشد. }
$$

هؤال هاى צ

$$
\text { زود شكل خرفته مىباشد. }
$$

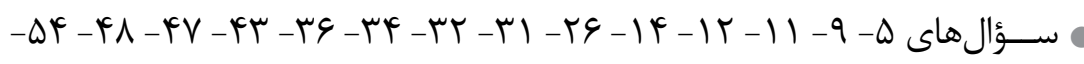

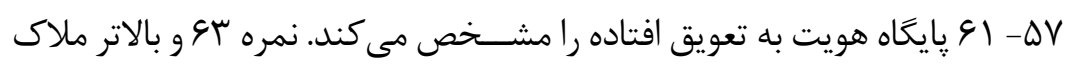

$$
\text { تشخيص קايكاه هويت به تعويق افتاده مىباشد. }
$$

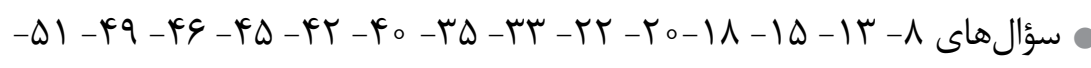

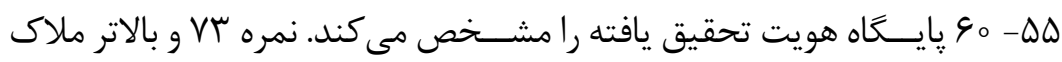


بنين و همكاران ( 9199 ()، ينج نوع روايى را در مورد اين يرسشنامه مورد بررسى قرار دادهاند. روايى بيشبين همزمان، روايى تحليل عاملى، روايى همگرا و واگرا. نتايج

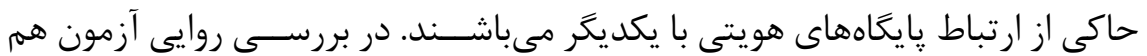
بستخى متوسطى بين مادههاى خرده مقياس هاى آزمون بهدست آمده است. ميانگين همبســتخى بين مادههاى خرده مقياس در بعد ايدئولوزيك و بين فردى براى هويت

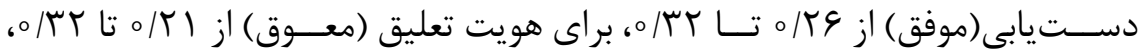

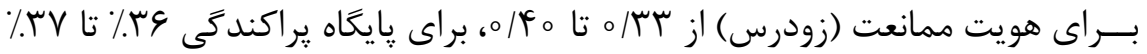
بود. يايايى اين يرســشنامه بر اســاس ضريب آلفاى كرونباخ محاسبه شده است كه بر اســاس اجراى مقدماتى، ضريب كل يايائى كل آزمون ه1 / ه، خرده مقياس هويت

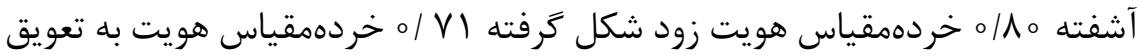

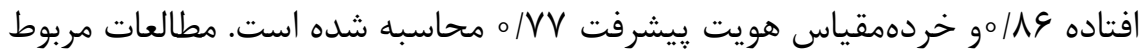
بـــه يايايى و ثبات درونى برحســب ضريب آلفاى كرونبــاخ در أ أمطالعه با ميانخين ع/4هبهدست آمده است. ضريب يايايى با روش آزمون مجدد در بين دانشجويان ايرانى

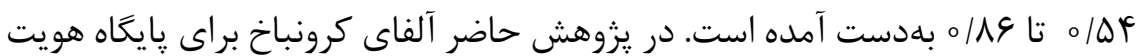

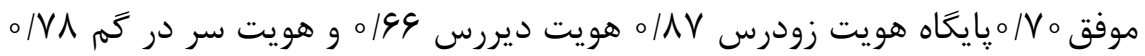
بلهدست آمد.

\section{يافتههاى يزوهش}

در ايــن بخش در ابتدا با اســـفاده از روش آمار توصيفى(فراوانى، درصد) به توصيف دادههاى يزوهش و در ادامه با استفاده از روش آمار استنباطى (آزمون ضريب همبستخى آنى اســـيرمن و يِيرســون و آزمون كولموگروف- اســميرنف) به تجزيه وتحليل سؤالهاى يزوهش يرداخته شده است. 


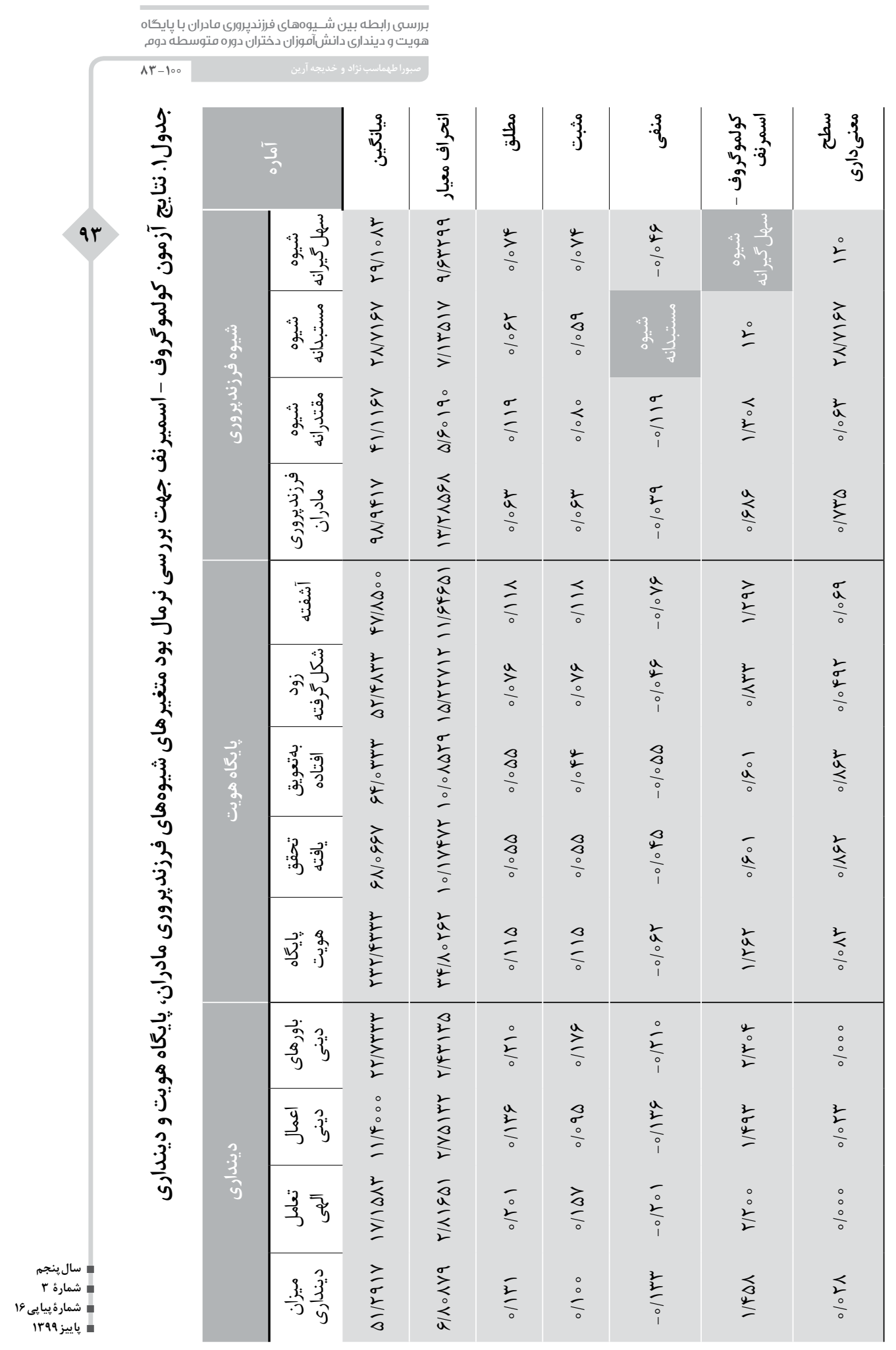


بر اساس سطح معنى دارى آزمون كولموكروف - اسميرنف فوق كه در تمامىمتغيرهاى مربوط به شيوههاى فرزنديرورى مادران و يايگاه هويت دختران بيشتر از هـ / است دليلى بر رد فرض صفر مبنىى بر نرمال بودن توزيع متغيرهاى مورد بررسـى نداريه. به عبارت ديخر همه مؤلفههاى شيوههاى فرزنديرورى مادران نرمال مىباشند. اما در متغير ديندارى متفاوت اسـت بدين معنى كه سطح معنى دارى آزمون كولموگروف- اسميرنف فوق در تمامى متغيرهــاى مربوط به ميزان ديندارى كمتر از هـ/ه اســت در نتيجه فرض صفر مبنى بر نرمال بودن توزيع متغيرهاى ميزان ديندارى رد مى گردد. به عبارت ديخر توزيع متغيرهاى ميزان ديندارى نرمال نمىباشند. از اين رو براى بررسى ارتباط بين متغيرهاى مورد مطالعه از تحليل رگرسيونى استفاده شــد براى تحليل رگرسيونى شيوههاى فرزنديرورى مســـتبدانه، سهل گيرانه و مقتدرانه بهعنوان متغيرهاى مســتقل و ميزان ديندارى و يايعاه هويت بهعنوان متغير وابســــه از روش كَامبه كام استفاده شد.

جدول r. يِيشبينى ميزان ديندارى دختران بر اساس شيوههاى تربيتى مادران

\begin{tabular}{|c|c|c|c|c|c|}
\hline سطح معنى ارىى & $\mathrm{F}$ & ميانتين مربعات & درجه آزادى & مجموع مربعات & منبع \\
\hline \multirow[t]{3}{*}{$\circ / \vee \wedge \circ(a)$} & o/TaT & $\mid V / 09_{0}$ & r & $\Delta / / 111$ & رَرسيون \\
\hline & & $F V / I I V$ & 119 & $\Delta F \Phi \Delta / 91 \circ$ & باقيمانده \\
\hline & & & 119 & $\Delta \Delta । \varepsilon / V q T$ & كل \\
\hline
\end{tabular}

سطح معنى دارى تحليل واريانس فوق بيشتر از ه ه/ه است كه نشاندهنده معنى دار نبودن اثر متغيرهاى مســتقل شــيوههاى مستبدانه، ســهل خـيرانه و مقتـدرانه در مدل ركرسيونى مىباشد. برايناســاس بين شيوههاى فرزنديرورى مستبدانه، سهل گيرانه و مقتدرانه و ميزان ديندارى دانشآموزان دختر مورد مطالعه رابطهُ معنى دارى وجود ندارد 


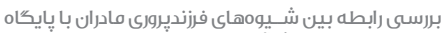

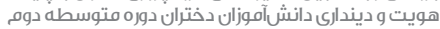

Ar-100

جدول r. يِيشبينى يايعاه هويت دختران بر اساس شيوه تربيتى مستبدانه مادران

\begin{tabular}{|c|c|c|c|c|c|c|}
\hline سطح معنى دارى & $\mathrm{F}$ & ميانگين مربعات & در جه آزادى & مجموع مربعات & منبع & مدل \\
\hline \multirow[t]{3}{*}{$\circ / 0 \circ \circ(a)$} & $\Delta \varepsilon / V \vee q$ & FENTEMII & 1 & FEATF/lIG & رَرسيون & \multirow{3}{*}{1} \\
\hline & & NTF/GVT & 111 & $q \vee \mu / 1 / r \Delta \circ$ & باقيمانده & \\
\hline & & & 119 & $|F F| r \Delta / F \& V$ & كل & \\
\hline \multirow[t]{3}{*}{ \%००(b) } & $F \Delta / Q \& V$ & mIVIO/Nof & r & GKFTI/GOD & ركرسيون & \multirow{3}{*}{ r } \\
\hline & & 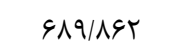 & $11 \mathrm{~V}$ & $\Lambda \circ \vee / r / \Lambda \Delta q$ & باقيمانده & \\
\hline & & & 119 & $|F F| r \Delta / F G V$ & كل & \\
\hline
\end{tabular}

بر اســاس جدول تحليل واريانس فوق در هر دو مدل ا و ب سطح معنى دارى آزمون تحليل واريانس كمتر از ه ه/ه اســت كه نشــاندهنده معنى دار بودن اثر متغير شــيوه مستبدانه در مدل ا و متغيرهاى شيوه مستبدانه و شيوه سهل گيرانه در مدل r مىباشد.

جدول F. . ييشبينى يايعاه هويت دختران بر اساس شيوههاى تربيتى مادران

\begin{tabular}{|c|c|c|c|c|c|c|}
\hline \multirow{2}{*}{ معنى سطارى } & \multirow{2}{*}{$t$} & \multirow{2}{*}{ ضر ضر يب استاندارد شهه } & \multicolumn{2}{|c|}{ ضرايب استاندارد نشده } & \multirow{2}{*}{ منبع } & \multirow{2}{*}{ مدل } \\
\hline & & & خطاى بر آورد & ضرايب & & \\
\hline$\circ / 000$ & $1 \% / 911$ & & $10 / 914$ & $10 \% / \Delta 99$ & مقدار ثابت & \\
\hline $0 / 000$ & V/DTA & $\circ / \Delta V_{0}$ & 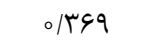 & r/VA。 & شيوه مستبدانه & \\
\hline$\circ / 000$ & $9 / 94 \Delta$ & & IT/KTQ & $11 \mathrm{~V} / \mathrm{gFV}$ & مقدار ثابت & \\
\hline 01000 & $\Delta / r 99$ & $\circ / 4 \circ V$ & $\circ / r V F$ & $1 / 914$ & شيوه مستبدانه & r \\
\hline$\circ / 000$ & $\varphi / q \circ \Delta$ & $\circ / T V V$ & $\circ / \mathcal{L} \circ r$ & 1/9v9 & شيوه سهل گيرانه & \\
\hline
\end{tabular}

بر اساس جدول ضرايبس در مدل r، مدل آمارى تحقيق عبارتست از: $y=117.947+1.984 x_{1}+1.976 x_{2}$

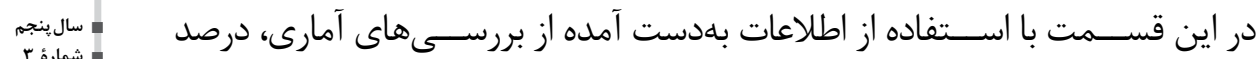

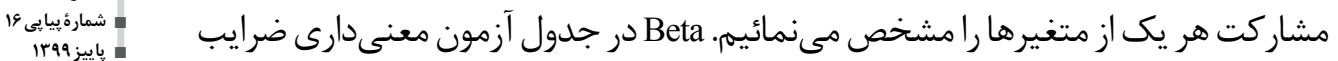


رگرســيونى، نشاندهنده ميزان تغيير متغير وابسته (براساس واحد انحراف معيار) به ازاى تغييرى به اندازه يك انحراف معيار در متغير مســتقل اســت. براين اساس متغير مستقل

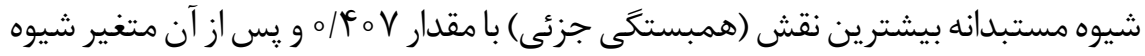

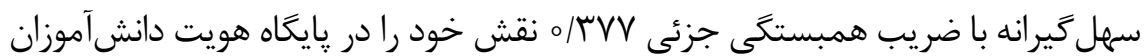
دختر ايفاء مى كنند. بر اساس مدل رَرسيونى فوق شيوه مقتدرانه رابطه معنى دارى با يايڤاه هويت دانش آموزان دختر نداشته است.

\section{بحث و نتيجه كيرى}

هدف از اين يزوهش رابطه بين شــيوههاى فرزنديرورى مادران و يايگاه هويت و ديندارى دختران بود. يافتههاى حاصله حاكى از اين است كه بين شيوههاى فرزنديرورى مقتدارنه مادران و يايگاه هويت دختران رابطه معنى دار وجود دارد. بدين معنى هنگًامى كه شيوههاى فرزنديرورى مادران، مقتدرانه (بازگَ نمودن دلايل تصميمهاى اتخاذ شـــده از ســـوى والدين، قانع نمودن بجههانسبت به محدوديتهاى ايجاد شده در خانواده درصورت اعتراض، راهنمائى كردن بهجاى تنبيه در صورت رفتار فرزندان برخلاف ميل والدين، دخالت دادن ونظرخواهى نمودن از فرزندان هنگَام تصميم گيرى درمورد مســائل و برنامههاى خانواده و...) مى گردد، پايعاه هويت آنان نيز (سيستم باورها، آرزوها، عقايد، مهارتها و تاريخهه فردى) باصصورت قوام يافته و منسجمترشكل مى گيــرد. والدين اقتدارگرا بهرغم كنترل بر فرزندان خويش نســبت به آنان انعطافيذير هم هســـتند. آنها با دليل و منطق شرايطى را كه مى خواهند فرزندانشان بِيذيرند توضيح مى دهند. طورى كه خودمختارى فرزندانشان را مىيذيرند و افكار نقادانه را تشويق مى كنند. اين والدين متوقع و در عين حال پاســـخَّويى هستـند. اين والدين داراى روشى گرم، يذيرند، فرزندمحور و در عين حال داراى كنترل متعادل هستند به فرزندان خويش اجازه مسئوليت متناسب با سن را مى دهند و محيطى را فراهم مى كند كه در حداكثر مصالح كودى براى تبديل شدن به يك فرد مطمئن و مستقل در آن موجود است. كودك اولين مرحله كسب هويت خود را از طريق ارتباط با والدين و نزديكان خود از خانواده كسب مى كند و اين را مىتوان نخستين و رايجترين سطح هويتى در جامعه بشــــى دانست. حال اخر والدين شيوه فرزنديرورى مقتدرانه است اين مسلماً روى هويت فرزند تأثير مناسب مى گذارد. يس نتيجه مى گيريم كه بين شيوههاى فرزنديرورى مقتدرانه و يايگاه هويت دختران رابطه وجود دارد. در تبيين نتايج اين يافته مىتوان كفت كه با توجه به اينكه در سال هاى اوليه زندگى كودك خودهاى متفاوتى دارد و از عدم ثبات بين آنهاو از 
فقدان وحدت و كليت رنج نمىبرد باظهور عمليات صورى نوجوان مى تواند بلصورت دروننكران

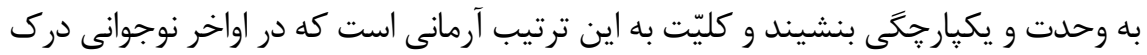

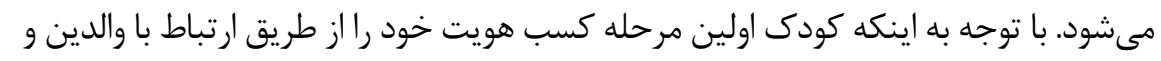

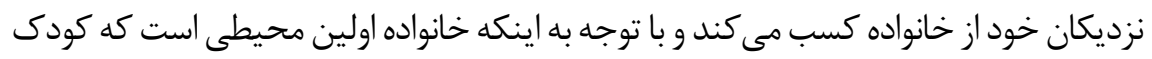

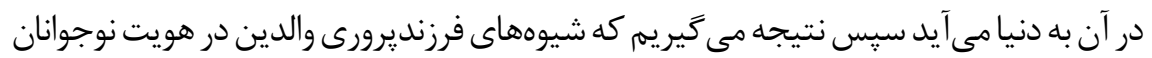

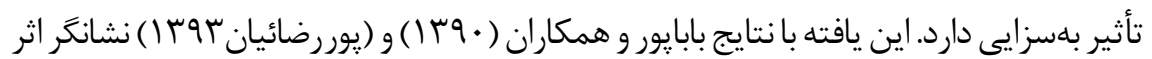

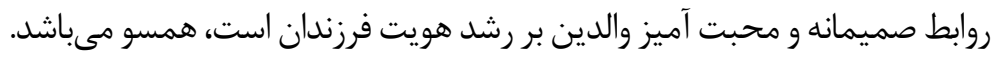

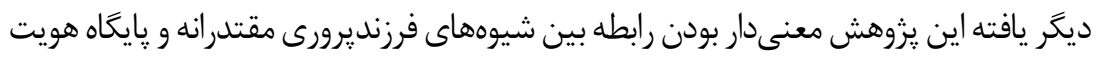

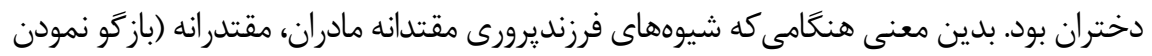

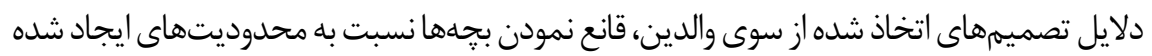

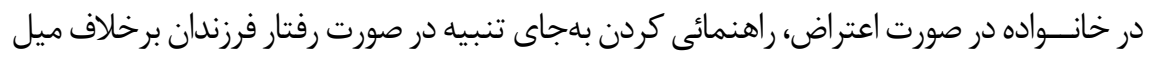

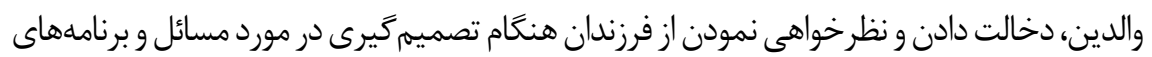

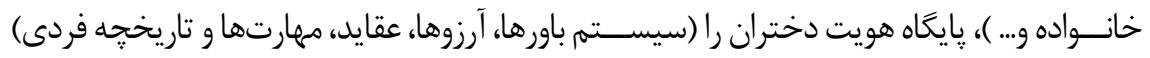

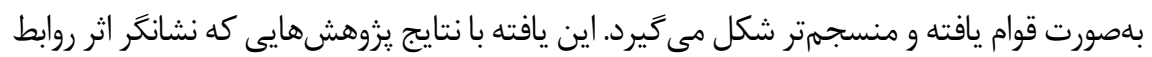

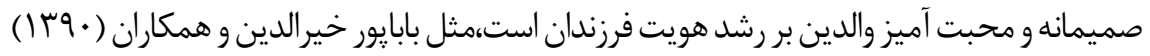

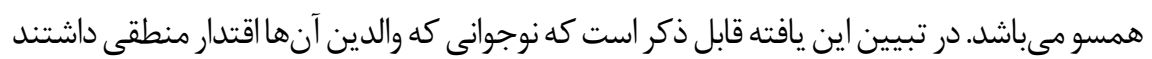

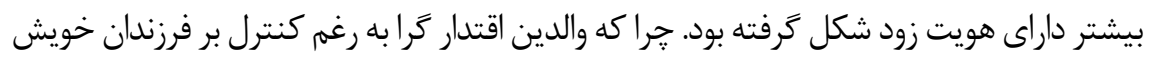

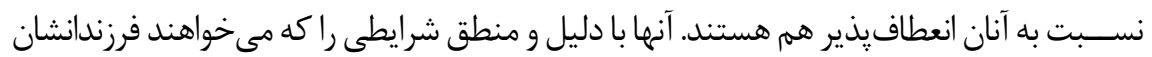

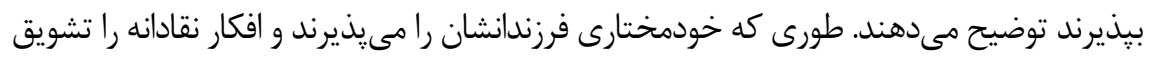

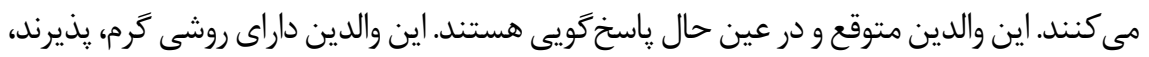
فرزندمحور و در عين حال داراى كنترل متعادل هستند به فرزندان خويش اجازه مسئوليت متناسب

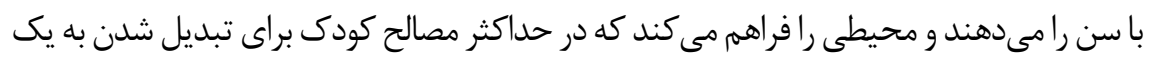
فرد مطمئن و مستقل در آن موجود است.

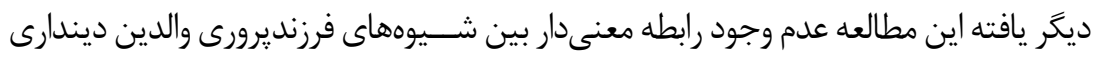

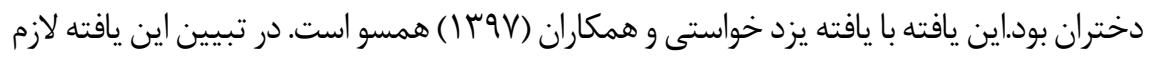

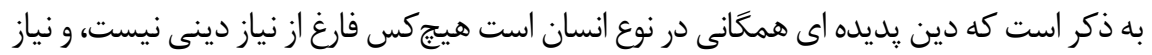

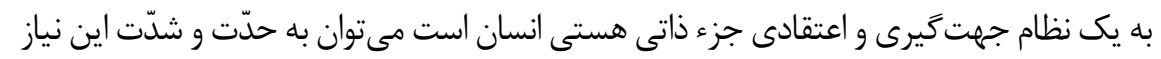

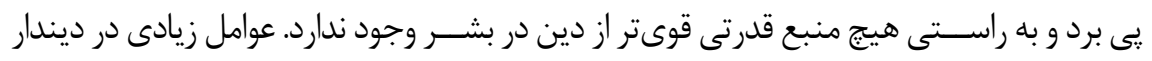


بودن فرزندان مؤثر است مثل عوامل فردى، اجتماعى، بهخصوص ديندار بودن والدين وغيره كه اينها عوامل مهممترى در ديندار بودن فرزندان هستندو والدين از هر نوع سبك فرزنديرورى استفاده كنند سبك فرزنديرورى شـان بر ديندار بودن فرزندانشان مرتبط نيست. يس با توجه به تبيين حاضر و

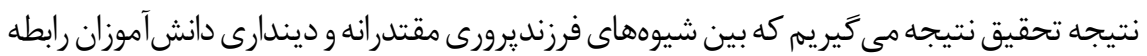

معنى دارى وجود ندارد. بر اســاس يافتههاى اين يزوهش مىتواند اطلاعات مهرمىبراى والدين، مربيان و مسئولان به همراه داشته باشــد. با توجه به آن كه نتايج اين يزوهش حاكى از نقش محبت و كنترل والدين در شكل گيرى سبكهاى يردازش هويت و مسئوليتيذيرى و همجنين نقش سيكهاى يردازش هويت در مســـوليتيذيرى نوجوانان مىباشد، ضرورت آكاهســازى خانوادهها در خصوص اثرات روشهاى تربيتى آنان بر رشـــد هويّت و مسئوليت يذيرى فرزندان بيش از ييش نمايان مىشود. در اين راستا پيشنهاد مىشود با توجه به آن كه در نظام تعليم و تربيت بر جايعاه خانواده تأكيد

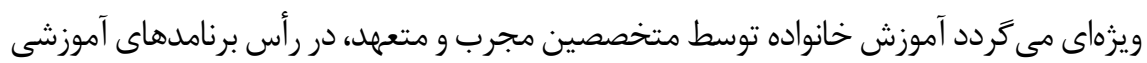
نظام تعليم تربيت قرار گيرد. با آموزش شيوههاى صحيح كنترل هدفمند همراه با گرمىو محبت، به والدين، مىتوان به ايجاد جو تربيتى مقتدرانه در خانوادهها كمك نمود و از اين طريق به بهبود روند شــكل گيرى هويت نوجوانان، شرايط مشاركت و مسئوليتيذيرى آنان در خانواده و اجتماع كمك نمود. علاوه بر اين با توجه به اينكه در يروهش حاضر تنها به كشــف روابط بين متغيرها

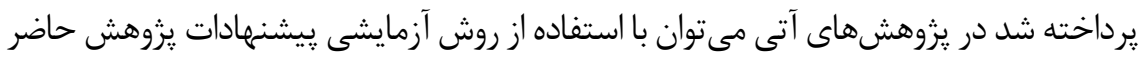

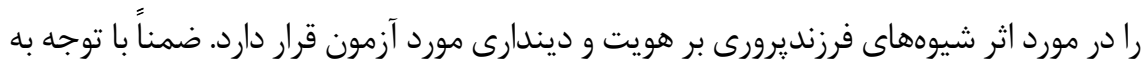
اين كه يافتههاى حاصله محصول مطالعه بر روى دانشآموزان دبيرستانى شهر بابل است در تعميم يافتههاى اين مطالعه به ديخر زيست و بومهاى متفاوت بايد تأمل نمود.

\section{تشكّر و قدردانى}

اين مقاله بر گرفته از ياياننامه كارشناسى ارشد در رشته مشاوره در دانشگاه علامه طباطبايى است. بدين جهت از همه اساتيد به ويزه اساتيد و دانش آموزان و اولياء دانشآموزان كه در اين بززوهش شركت كردند سياسگزارى مىشود. 


\section{منابع}

$$
\begin{aligned}
& \text { اســفنديارى، غلامرضا. ( I I ). بررسى و مقايسه شــيوههاى فرزنديرورى كودكان مبتلا به اختلالات رفتارى و مادران }
\end{aligned}
$$

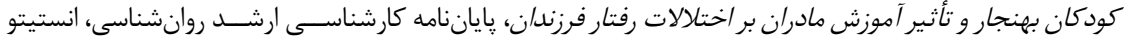

$$
\begin{aligned}
& \text { روانيزشكى تهران. }
\end{aligned}
$$

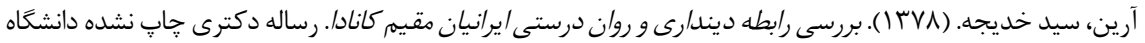

$$
\begin{aligned}
& \text { علامه طباطبايى. }
\end{aligned}
$$

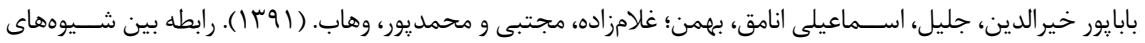

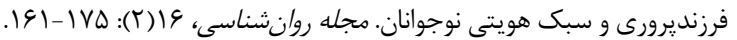

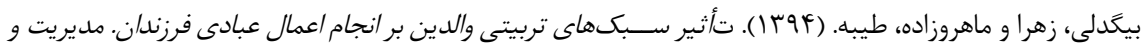

$$
\begin{aligned}
& \text { برنامه ريزى در نظام آموزشى. زهر ماده. }
\end{aligned}
$$

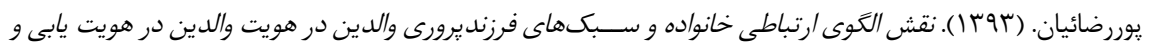

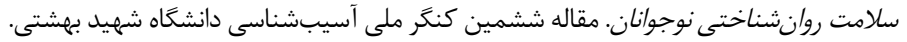

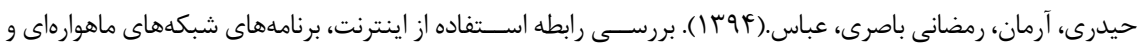

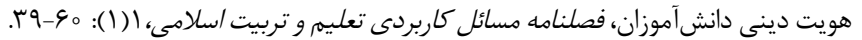

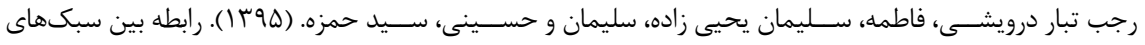

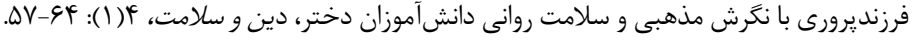

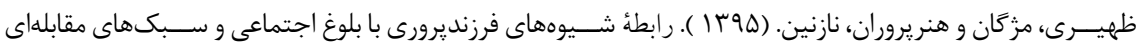

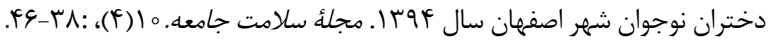

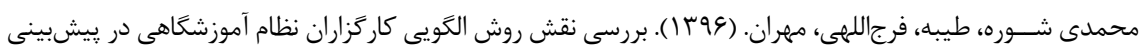

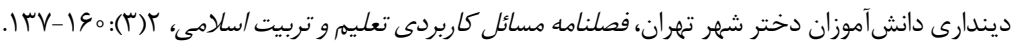

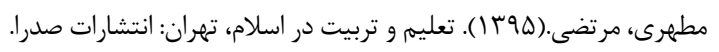

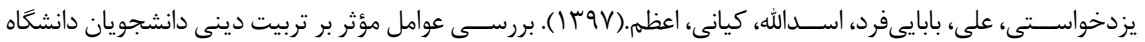

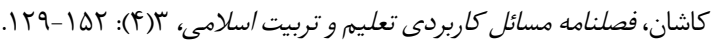

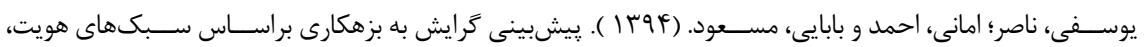

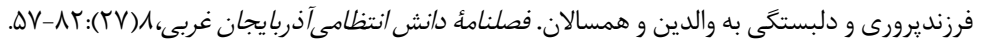

\section{REFERENCES}

Abbotts JE, Williams RG, Sweeting HN, West PB.(2004). Is going to church good or bad for you? Denomination, attendance and mental health of children in West Scotland. Social.

Ahmadi F, Taghipoor E, Khodabakshi Kulaei A. (2010). The comparison of the Objective Measure of Ego-identity Status: An identity instrument for use with late adolescents. Journal of Adolescent Research, 1, 183-198.

Bennion, L. D., \& Adams, G. R. (1986). A revision of the Extended Version of the Objective Measure of Ego-identity Status: An identity instrument for use with late adolescents. Journal of 
performance. Personality and Individual Differences, 39(1), 235-247.

Cassidy, T. (2011). Family background and environment, psychological distress.

Dudley L. Poston, J. R. (2014). The Family and Social Change in Chinese Societies.The Springer Series on Demographic Methods and Population Analysis, Journal of Early Adolescence, 34(2), 521-528.

Erikson, E. H. (1970). Autobiographical notes on the identity crisis. Daedalus, 99(4), 730-759.

Habiballah Nataj, L., Jadidi, M., \& Tirgarei, A. (2013). A comparison of parenting styles, perfectionism and psychological problems of university students.International Journal of Basic Sciences \& Applied Research, 2(7), 697-702, Available online at http://www.isicenter.org.

identity formation styles in teenagers with/without substance abuse. J ResAddic.

Juvenile delinquency, Psychology, 2, 941-947.

Marcia, J.E. (1980). Identity in adolescence. In J. Adelson (Ed.), Handbook of adolescent psychology (pp. 159- 187). New York: Wiley.

Mendonca, M., Fontaine, A. M., (2014). The role maturity of parents of emerging adult children: validity of parental maturity measure. Journal of Adult Development, 21(2), 116-128.

Papalya, D. A. (2016).Developmental psychology and human development. Translation Quhistani et al Tehran:growth.

Savicki, V., \& Cooley, E. (2011). American identity in study abroad students: Contrasts, changes, correlates. Journal of College Student Development, 52(3), 339-349.

Science \& Medicine. 58(3):645-56.

Uji,M. Sakamoto, A., Adachi, K. \& Kitamura, T. (2014).The impact of authoritative, authoritarian, and permissive parenting styles on children's later mental health in Japan: Focusing on parent and child. Journal of Child and Family Studies, 23(2),293-302.

Zare, F., Bakhshipour, B., \& Hassanzadeh, R. (2014). Parenting style and mental health in Iranian adolescents. Journal of Novel Applied Sciences. Available online at www.jnasci.org.

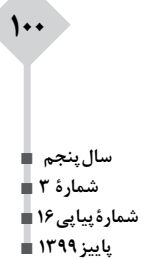

